\title{
Tourism and Counterurbanization in a Low-Amenity Peripheral Island: A Longitudinal Study at Yakushima Island in Kagoshima, Japan
}

\author{
Rie Usui ${ }^{1, *(1)}$, Carolin Funck ${ }^{1}$ and Ifeoluwa B. Adewumi ${ }^{2}$ \\ 1 Graduate School of Humanities and Social Sciences, Hiroshima University, Higashihiroshima 7398522, Japan; \\ funckc@hiroshima-u.ac.jp \\ 2 Graduate School of Integrated Arts and Sciences, Hiroshima University, Higashihiroshima 7398521, Japan; \\ i.b.adewumi@gmail.com \\ * Correspondence: leahrieusui@hiroshima-u.ac.jp; Tel.: +81-82-424-6686
}

Citation: Usui, R.; Funck, C.;

Adewumi, I.B. Tourism and

Counterurbanization in a

Low-Amenity Peripheral Island: A Longitudinal Study at Yakushima Island in Kagoshima, Japan. Sustainability 2021, 13, 8822. https:// doi.org/10.3390/su13168822

Academic Editor: Stephen Royle

Received: 22 June 2021

Accepted: 4 August 2021

Published: 6 August 2021

Publisher's Note: MDPI stays neutral with regard to jurisdictional claims in published maps and institutional affiliations.

Copyright: (c) 2021 by the authors. Licensee MDPI, Basel, Switzerland. This article is an open access article distributed under the terms and conditions of the Creative Commons Attribution (CC BY) license (https:/ / creativecommons.org/licenses/by/ $4.0 /)$.

\begin{abstract}
This research explored the long-term relation between tourism development and counterurbanization in a remote island in Japan, as the longevity of in-migrants' role in low-amenity tourism destinations has been questioned. Using data collected over 10 years at Yakushima Island, the study investigated the island's population trend, in-migrants' motivation for relocation, their contributions to tourism, and the lives on the island. The results showed that the trend of population growth differed among Yakushima's 24 villages likely because of accessibility, proximity to tourism attractions, the weather, and housing availability. Yakushima's natural environment was the key factor in in-migrants' migration choice. Encounters and connections with people on the island were found to be another important factor. In-migrants introduced ecotours as an innovation in the 1990s, and thereafter, many in-migrants moved to Yakushima with high aspirations of becoming tour guides. Tourism stagnated starting in 2008, and some in-migrants began moving out of the island. Despite the overall downward trend of tourism, an increase in international tourists created a niche market before the COVID-19 pandemic, attracting foreign in-migrants as tourism entrepreneurs in recent years. Similar to the main driver for Japanese in-migrants' relocation, nature was also the main motivation for international tourists' relocation.
\end{abstract}

Keywords: counterurbanization; tourism development; nature-based tourism; Yakushima Island; peripheral island; low amenity; longitudinal study

\section{Introduction}

Tourism and migration hold a symbiotic relationship, in which one generates flows for the other and vice versa [1]. Counterurbanization, a phenomenon in which people relocate from urban to rural areas [2], is fueled by such a symbiotic relationship, especially after the 1990s, when the demand for tourism and migration to rural communities began to grow [3]. Unlike post-industrial in-migrants who seek employment opportunities, in-migrants to rural communities are typically motivated to seek a better quality of life [4]. Their motivations are driven by their negative or unsatisfactory lifestyles before migration [5]. One push factor of urban-to-rural migration occurs when people are fed up with life in the urban space because of gentrification processes [6]. Disgust of a consumerism society also plays a part in driving people to escape from their urban lives [7].

In the process of migration, people change their locations over time [4], and tourism can be an initial step in this process [8,9]. Previous visits to a destination may contribute as a factor in drawing tourists back to their destination as migrants or permanent residents [9]. Some even start tourism-related businesses after relocation [10,11] with varying motivations. There are those who have a clear vision of starting up their businesses prior to migration [12], whereas others become self-employed by accident or out of financial 
necessity [13]. Some are more reliant on their income from the business, whereas for others, it is a side business [14], and they are motivated to share their lifestyle dream with like-minded clients [15]. They may consider the tourism business as a way to combine their hobbies with work [16].

Rural communities characterized by socio-economic downturn, a scarce population, and a relative deficiency in services and infrastructure are called low-amenity rural areas $[10,17]$. Despite their limited resources, they offer a quality of life that in-migrants seek, which is associated with a combination of material and intangible aspects, including lower property rates [7], better environmental conditions [7], rural environments, and places that offer slow and simple lives or that are safe and free from any external constraints [18]. They often provide natural and aesthetic assets that allow in-migrants to live their desired lifestyles [16].

There have been mixed findings regarding in-migrants' contributions to rural communities. While some studies claim that in-migrants can potentially provide benefits to the economic development of rural areas [11,12], others question their contributions because lifestyle is often a prioritized aspect over business or economic achievement among urban-to-rural migrants $[14,19]$. In low-amenity rural areas, in particular, in-migrants value the experiential dimension of their lifestyle, which relates to their hobbies [13], and may consider work-life balance more important [20]. Rurality or underdevelopment is often a preferred character, which provides the basis for the slow life that many in-migrants seek for [10]. Thus, if rural areas develop through tourism, they may no longer become attractive places for in-migrants. Consequently, this raises a question about the long-term symbiosis of tourism development and counterurbanization in low-amenity rural places.

The life stage of in-migrants likely affects their duration of migration [12]. For instance, young in-migrants may be motivated to move to low-amenity rural areas during a certain stage of their lives, but they may not stay for the long term as they enter into the next stage of their lives [10]. Using the case of a winter tourism destination in Northern Sweden [10], Carson et al. questioned the longevity of in-migrants' role in low-amenity areas, as very few respondents in the study had long-term plans. Similarly, Kuentzel and Ramaswamy [21] concluded that there is a weak link between the availability of tourism amenities and counterurbanization in Stowe, Vermont in the US, a mountain resort. While Carson et al. [10] and Kuentzel and Ramaswamy [21] investigated counterurbanization and tourism connections in the long term, the spatial locations of low-amenity rural communities vary-some are located near urban fringes, whereas others are located in peripherals-and attract different types of in-migrants [22].

Islands are good models for examining the connection between tourism and counterurbanization, as tourism has become a key industry for many islands [23], and islands can be one type of migration destination that perfectly fits the expectations of rural in-migrants. Islands play a special role because of their strong image in tourism; they are perceived to offer fantasy or even a paradise and provide people with an opportunity to escape from their normal life [24]. Islands of "particular perceived charm" [25] (p. 471) are especially qualified to attract second homes and retirement migration. As a result of benefitting from tourism, in such islands, economics and populations can stabilize or even grow [26,27]. Yet, as found in previous studies, the long-term effects of counterurbanization in lowamenity tourism destinations are questionable $[10,21]$ and require further investigation in the peripheral island context, where tourism is expected to play a strong role in counterurbanization. Therefore, the present study discusses the long-term counterurbanization and tourism nexus in the context of a peripheral island location in Japan that experiences youth out-migration and aging.

Japan provides useful cases for examining the connection between tourism and counterurbanization in the island context, as it is a country consisting of nearly 7000 islands [28], and many of these islands have been struggling to revitalize their communities because of their narrow economic base and limited resources [29]. Islands are generally regarded as fragile places, both economically and ecologically, because of their small size, insu- 
larity, isolation, and vulnerability to natural disasters [29]. These limiting characteristics of islands lead to the continuous outpouring of younger generations to cities. The loss of younger generations could then lead to a workforce reduction and an increase in the aging population. In such communities, tourism is often used as a means of revitalization [30], and counterurbanization trends are considered a key factor that affects aging and depopulation.

Counterurbanization in Japan became a popular topic during the oil crisis in the 1970s. Although it was never strong enough to become an actual trend, it has attracted renewed interest from the media and researchers in recent years [31]. Since the 1970s, several steps in the development of counterurbanization have been recognized. After the oil crisis, employed sarariman (salaried permanent workers) dropped out of their permanent jobs before retirement and relocated to the countryside using their retirement money to build mostly Western-style inns called penshon [32]. In the 1980s, a revived interest in rural things and places made tourists and in-migrants reappreciate rural heritage and idealize rural landscapes as furusato (hometowns) [33]. After the bursting of the bubble economy in the early 1990s, the structural instability of the labor market created some fluctuation out of urban centers. Since the early 2000s, young people started moving to the countryside [34], but retirement migration, especially for the first baby boom generation, also proceeded. In 2009, the national chiiki okoshi kyoryokutai (Community Building Support Staff Program) started to match young people and communities by providing financial support for three years, during which in-migrants should set up their own way of making a living [34].

The Great East Japan Disaster in 2011 accelerated the search for new lifestyles [34,35]. In 2014, the government embarked on a policy for the revival of the countryside called den'en kaiki, which is considered by some to be a possible beginning of counterurbanization [36]. It can be assumed that the COVID-19 crisis in 2020 will become another factor driving migration to rural areas, as dense living conditions in urban centers prove to be a disadvantage during the pandemic.

The increased focus on migration is mirrored in international and Japanese research on the topic (e.g., [35,37]). In-migrants are commonly divided into U-turners (i.e., those who return to their hometown after a period of absence) and I-turners (i.e., those who move to areas to which they are not connected in any way) [35]. However, as Klien pointed out [35], semi-permanent moves are more common, and there is no such phenomenon as a typical migrant. Diverse narratives, practices, and motives attract people of different ages and genders to the countryside, where they look for work, their own self, a place to settle down, or a life that contributes to society [34]. Even nationality becomes fluid, as Japanese with international partners or experience in life abroad increasingly choose a new lifestyle in rural areas (e.g., through the Community Building Support Staff Program).

While many island communities in Japan fail to reverse their declining trend in population, and municipalities across the country compete to attract in-migrants, some localities have successfully secured large numbers of new inhabitants. In Yakushima Island, the focus of the present study, the constant influx of in-migrants has helped slow down the rate of population decline for over a decade. The island is a well-known nature-based tourism destination in Japan. It was designated as a UNESCO World Natural Heritage site (WNHS) in 1993 and has thus far received more publicity for issues connected with the management of its environmental resources [38-40] than for issues related to the constant flow of in-migrants.

The present study contributes to the knowledge of tourism and counterurbanization at a low-amenity tourism destination; their long-term relationship has been questioned in non-island contexts. Given its remote location away from mainland Japan and the general Japanese indifference toward the idea of moving to islands [36], Yakushima Island provides valuable insight into the counterurbanization and tourism nexus. Specifically, the study analyzes the 10-year trend of Yakushima's in-migrants. Our research questions are twofold: In the context of a low-amenity peripheral island destination, (1) do in-migrants contribute to stabilizing the population in the long term? (2) How do they contribute to 
improvements in the tourism sector? The aim is to identify the motivations of in-migrants, the factors that make Yakushima an attractive destination for migration, and changes in migration patterns during the different tourism development stages. We will also explore the reciprocal connection between the role of tourism as a sector that creates business and livelihood opportunities for in-migrants and the role of in-migrants in developing tourism. The findings of the study would be useful not only for Japan's peripheral island tourism destinations but also for those outside Japan that are experiencing depopulation and aging.

\section{Overview of Yakushima Island}

Yakushima Island (Figure 1) is located in southern Japan, approximately $60 \mathrm{~km}$ off the southern tip of the coast of Kagoshima Prefecture. It has a total area of $500 \mathrm{~km}^{2}$, of which $90 \%$ is covered by mountains. Several mountain peaks of over $1800 \mathrm{~m}$ are located in the central part of Yakushima, resulting in people settling in 24 communities along the coastline.

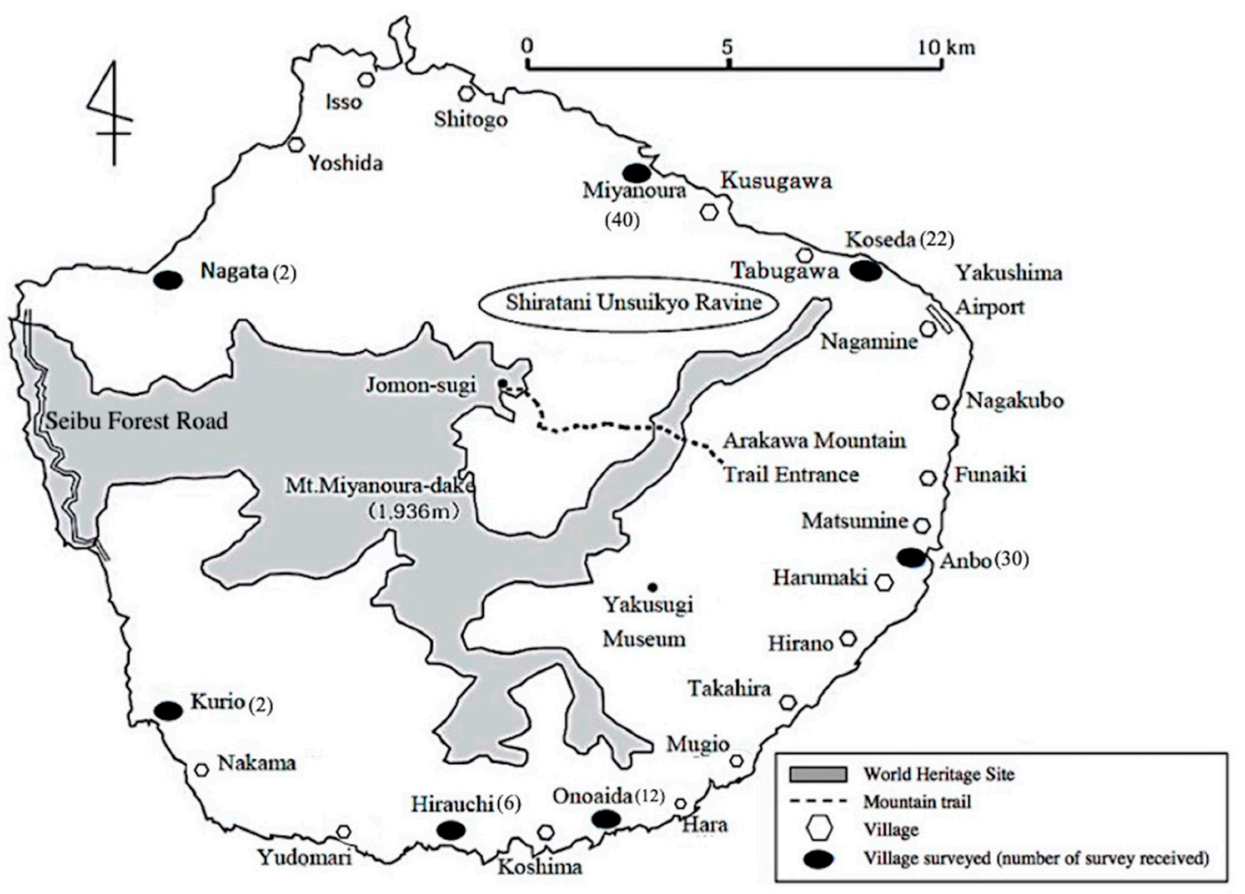

Figure 1. A map of Yakushima, including the communities surveyed in 2015 (see Section 3) (adapted from [41]).

Because of its topographical features and remote location-the island is situated in a location where the Kuroshio Current forms-Yakushima Island receives abundant rainfall annually ( $4500 \mathrm{~mm} /$ year in the relatively dry and flat regions and $8000-10,000 \mathrm{~mm} /$ year in the mountainous regions). The island's climate varies widely, from subtropical at lower elevations to subarctic zones at higher elevations. Yakushima's climate has led to the development of numerous flora (more than 1900 species) and fauna (16 confirmed species) that are endemic to the island. Yaku-sugi cedar, an endemic flora, is a type of Japanese cedar found in the southernmost part of Japan [42]. Jomon-sugi cedar, which is considered the largest in Japan, is the most notable Yaku-sugi cedar on the island. Another feature that is part of Yakushima's flora is the moss. There are reportedly over 600 species of mosses in Yakushima [43].

The tourism industry has played a significant role in the island's economy, replacing forestry when it was stopped for environmental concerns. With its designation as a national park in 1964 and the start of speedboat service in 1989, the island started attracting tourists [44] (Figure 2). Later, the number of tourists continued to increase because of Yakushima's registration as a UNESCO WNHS. The annual number of tourists exponen- 
tially increased from approximately 100,000 between the 1970s and mid-1980s to 406,000 in $2007[45,46]$. However, it has been in decline since 2008 [47].

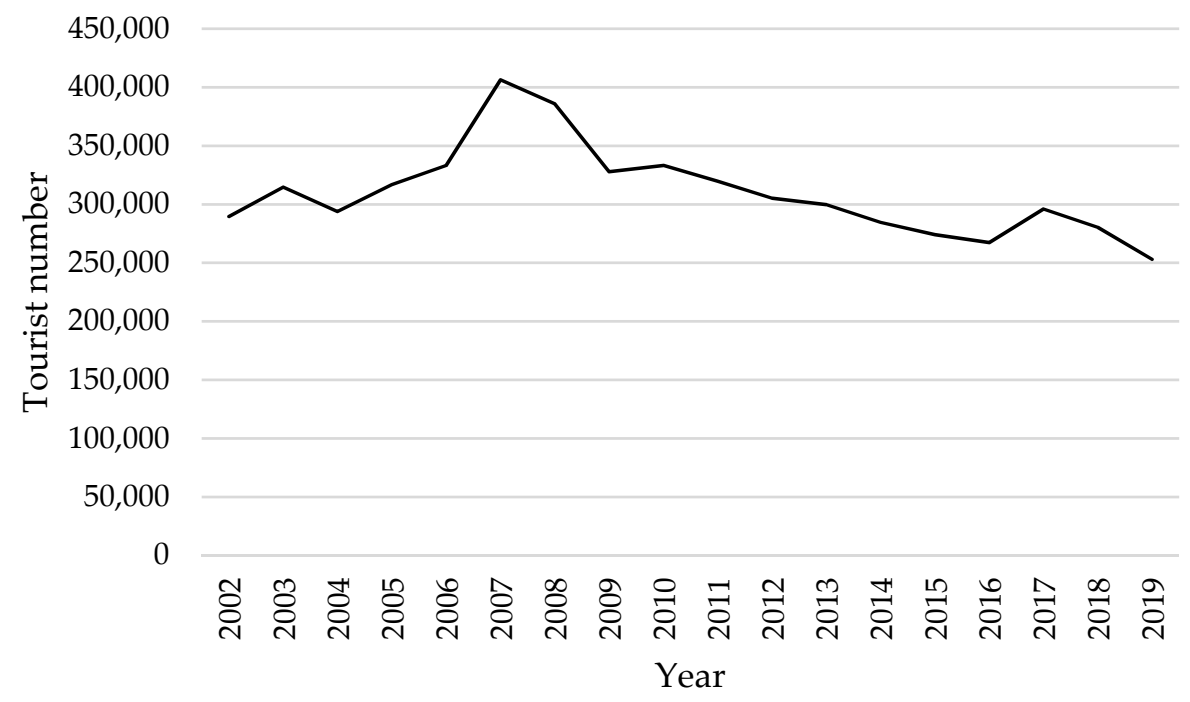

Figure 2. Number of incoming visitors to Yakushima Island in 2002-2019 (Source: [48]).

Most tourists who visit Yakushima Island are drawn to see the old Jomon-sugi cedar tree [45] and two mountain areas equipped with easy hiking paths that feature other large cedar trees and moss forests. Hiking is a major tourist activity, but the island also offers marine-based activities, such as sea turtle watching, snorkeling, scuba diving, and kayaking. Yakushima is one of the few places in Japan where guided ecotours to visit natural attractions have become a standard part of the tourist experience [45].

With the growth in tourist numbers, opportunities have emerged for work in the tourism sector. The most obvious sectors are accommodations, restaurants, guides, souvenir shops, and rental cars [49]. Results from our fieldwork revealed that other businesses have a stronger place-specific aspect, such as the preparation and distribution of lunchboxes for hikers, renting gear for outdoor leisure, and the production of souvenirs made from Yaku-sugi wood and food from local resources, such as flying fish, deer, and tea.

Among these different types of occupations, mountain and ecotour guides have become symbols of the connection between migration and tourism [50]. While mountaineering guides existed long before World Heritage registration, the first specialized ecotour guide groups were founded in 1989 and 1993 by in-migrants. At one point, a number of 200 ecotour guides, of which $80 \%$ originate from outside Yakushima, became common knowledge among researchers based on material provided by Yakushima town. Data from 2007 , when the first tentative registration system was introduced, showed that only $31 \%$ of 116 registered guides originally came from Yakushima, but it can be assumed that many local guides did not register themselves [50]. Ecotours can be considered an innovative practice brought to Yakushima by in-migrants, many of whom have specialized knowledge of ecology or outdoor leisure experience [45]. A low initial investment, the absence of quality or proficiency control, the increased interest in nature-based tourism in Japan, developing possibilities of direct marketing through the internet and social networking services, and finally the chance to start as a member of an ecotour guide company or group have made this sector the easiest entrance path for in-migrants to Yakushima.

Clearly quantifying the tourism industry in Yakushima is difficult, as different data sources are based on different criteria. Data for the whole town of Yakushima include a very small number of facilities on a second small island that is not the topic of this study. One such statistic, the Economic Census of Japan, started in its current form in 2012. That year, it accounted for 232 establishments in the sector of "Accommodations, eating and drinking services"; this number increased to 285 in 2016. 
Statistics published by Kagoshima Prefecture show about 50 accommodation facilities at the time of the UNESCO WNHS registration. That number climbed through the years to 108 (2000) and 181 (2007) to reach a peak with 238 facilities in 2014. It has since declined to 229. However, it is based on the number of operation licenses for accommodation, so it may include facilities that own a license but are actually out of business [51]. Many tourism businesses register as members of the Yakushima Tourism Association. In 2010, these included 138 accommodations and 48 eating and drinking services. This number declined to 81 and 29 in 2019. Once again, this may not reflect real numbers, as internet advertising and reservation systems have made businesses less reliant on services provided by the Yakushima Tourism Association, so they could simply have decided against membership. As statistics from Kagoshima Prefecture suggest an increase that might only reflect the number of license holders, the membership numbers of the Yakushima Tourism Association imply a decrease that could be based on changed membership behavior. It is therefore impossible to give a correct account of the change in the number of tourism businesses.

Guides are not classified as a separate group in any official statistics, so their numbers can be grasped only from guide registration systems. As mentioned above, 116 guides were registered in the first ecotour guide system in 2007; as of 2021, 75 guides are listed as Official Certified Guides of Yakushima Guides by the town [52]. At the same time, the Yakushima Tourism Association has 134 members in its guide sub-group [53]. During interviews, guides often mention that they draw on part-time guides during peak seasons, so we can assume that not all guides on the list are full-time professionals.

\section{Materials and Methods}

The present research adopted a longitudinal case study, which is considered invaluable in using a single-case research design [54]. This long-term study allowed us to analyze counterurbanization trends at different stages of tourism development in Yakushima. The study used mixed methods of data collection, including secondary data published by the municipal or national governments, questionnaire surveys, and semi-structured interviews. To understand the migration trend in Yakushima Island over the last few years, the study first analyzed the overall population of the island and the population trend by village using secondary data.

The primary data were derived from several research projects conducted in Yakushima between 2009 and 2020 concerning tourism development on the island. The first project, from 2009 to 2011, focused on how tourism influenced the destination as a whole. It helped us discover the important role that in-migrants played in tourism in Yakushima. The questionnaire that formed the main part of the following project in 2015 created an overview of different business sectors that, for the first time, allowed for the quantification of inmigration and the reasons behind it. The third project, conducted in 2017 and 2018, focused on Japanese tour guides, their motivations behind moving to the island, and how they make a living on the island, as ecotour guides are representative of a strong connection between tourism and counterurbanization on Yakushima Island [50]. During this 2017 project, we discovered a few international in-migrants who are active in tourism businesses. This led to the follow-up project in 2020 focused on this subgroup, which reflects the shift from domestic to international tourism in Japan in the 2010s. All projects were conducted in groups in which the researchers were in charge of designing the concepts and surveys, and the investigators helped collect the data.

Although each project had different goals and objectives, meaning that the contents of the interview questions slightly varied, questions related to the respondents' background information were commonly asked during the interviews. While not all interviews were conducted by the same investigators, all were skilled at conducting interviews. Additionally, to secure continuity, some researchers and investigators participated in several projects. Thus, the high data quality was maintained, and it was relatively consistent across different research periods. 
As some interviews were conducted by different researchers as part of their own research projects, some overlap of respondents might exist between the different projects. Records of the interviews were kept by institution (i.e., hotel, tour company) and, for privacy reasons, not by interviewee name. Even if the interviews were conducted in the same institution, after several years, ownership changed, and different persons were interviewed. As the questionnaire survey was conducted anonymously, we were unable to identify the respondents' identities. Therefore, the data were analyzed and reported separately by research period to determine changes in migration patterns and the way in-migrants became involved in tourism in Yakushima.

Table 1 presents the methods used in each fieldwork. From 2009 to 2011, a total of 46 semi-structured interviews with tourism businesses were conducted by visiting facilities during the off-season in February. The results of the study between 2009 and 2011 were grouped into three periods of tourism growth in Yakushima: Period 1-before 1992, when the island was not yet registered as a World Heritage site; Period 2-10 years between 1993 and 2002, when the island started experiencing tourism growth; and Period 3-2003 to 2011 , a period of rapid growth followed by tourism stagnation.

Table 1. Research periods, methods used, contents, and number of respondents.

\begin{tabular}{|c|c|c|c|}
\hline Research Period & Method & Contents & No. of Respondents \\
\hline 2009-2011 & $\begin{array}{l}\text { Semi-structured } \\
\text { interviews with } \\
\text { tourism businesses }\end{array}$ & $\begin{array}{c}\text { Situation of and } \\
\text { problems in tourism } \\
\text { Story of the } \\
\text { business/owner }\end{array}$ & 46 \\
\hline 2015 & $\begin{array}{l}\text { Questionnaires } \\
\text { administered to } \\
\text { tourism businesses }\end{array}$ & $\begin{array}{l}\text { Type of the business, } \\
\text { length of residency, } \\
\text { and opinions on } \\
\text { ecotourism }\end{array}$ & 114 \\
\hline 2017 and 2018 & $\begin{array}{l}\text { Semi-structured } \\
\text { interviews with tour } \\
\text { guides and town } \\
\text { officials }\end{array}$ & $\begin{array}{l}\text { Reasons for } \\
\text { migration, how to } \\
\text { make a living, } \\
\text { and information on } \\
\text { migration policies, } \\
\text { including support } \\
\text { programs }\end{array}$ & 16 (tour guides) \\
\hline 2017 and 2020 & $\begin{array}{c}\text { Semi-structured } \\
\text { interviews with } \\
\text { international } \\
\text { in-migrants }\end{array}$ & $\begin{array}{l}\text { Reasons for } \\
\text { migration, } \\
\text { the business, } \\
\text { and problems }\end{array}$ & 6 \\
\hline
\end{tabular}

In 2015, structured questionnaires were administered to tourism businesses. For the sample selection, 150 tourism-related businesses in seven communities were randomly selected from the list of businesses registered as of 2015. The questionnaire was in Japanese and then translated into English for analysis. Data analysis was carried out on 114 usable questionnaires. Both descriptive statistics and Chi-square test were computed using SPSS 25 software. The results of the study in 2015 were grouped into four periods: Period 1-years before the WNHS designation (before 1992); Period 2-period of early tourism growth (1993 to 2000); Period 3-period of rapid tourism growth (2001-2007); and Period 4-period of tourism stagnation and decline (2008-2015).

Semi-structured interviews were performed in 2017 and 2018 with 16 in-migrants who work as tour guides, with Yakushima town officials in 2018, and with six international inmigrants in 2017 and 2020 who were involved in the tourism business. For the interviews, tour guides were contacted beforehand because many of them did not have an office. Other businesses, such as accommodations, restaurants, and cafés, were visited without appointments, and interviews were conducted on the spot. Interviews were recorded upon the agreement of the interviewees and later transcribed. While conducting fieldwork 
in 2018, one of the authors had an opportunity to talk with some locals and in-migrants outside the official interview listed in Table 1 . The relevant information they shared related to migration will also be reported anecdotally.

As mentioned above, quantifying tourism businesses in Yakushima and their changes over the years is difficult, so the relation of the sample numbers to the overall business sector cannot be defined exactly. If we consider membership of the Yakushima Tourism Association or registered guides as minimum numbers, at the start of our research, the number of accommodations would be above 138 facilities and that of guides would be above 116 persons, to name the two most prominent sectors. The number of international inmigrants in the tourism sector is even more difficult to grasp. From the interviews, we heard about two more persons who could have been possible candidates for our research. However, as the Population Census counts only 73 non-Japanese residents in Yakushima in 2015 , the overall number is very small.

\section{Results}

\subsection{Population Trend in Yakushima}

Figure 3 shows Yakushima Island's population trend from 1950 to 2020. As of 30 April 2021, the population of the island is 12,026 [55]. Although the population has been in decline since 1960 , in contrast to many other remote islands in Japan, the rate of decline has slowed down over the last 30 years.

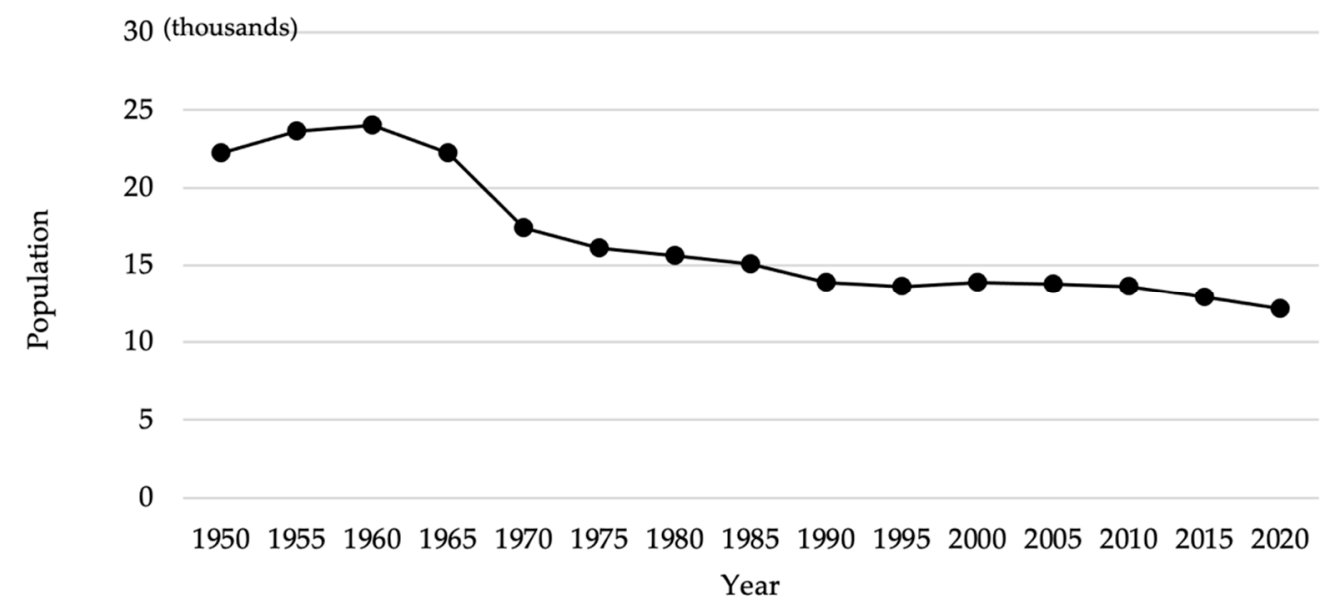

Figure 3. Population trend of Yakushima Island since 1950 (Source: $[47,48,56]$ ).

The detailed population trend was further analyzed by village, as shown in Figure 4. The villages whose population increased from 1990 to 2020 are indicated in orange, and those that experienced population decline are indicated in blue. The size of the circles represents the rate of growth and decline. Out of 24 villages, 10 had an increased population from 1990 to 2020, and they are located on the southwest side. Among them, Matsumine had the highest rate of population increase, which was more than $50 \%$, from 329 in 1990 to 503 in 2020. Nagamine and Hirauchi followed, with their population increase rates at $39.1 \%$ (284 to 395 ) and $34.6 \%$ (482 to 649 ), respectively. 


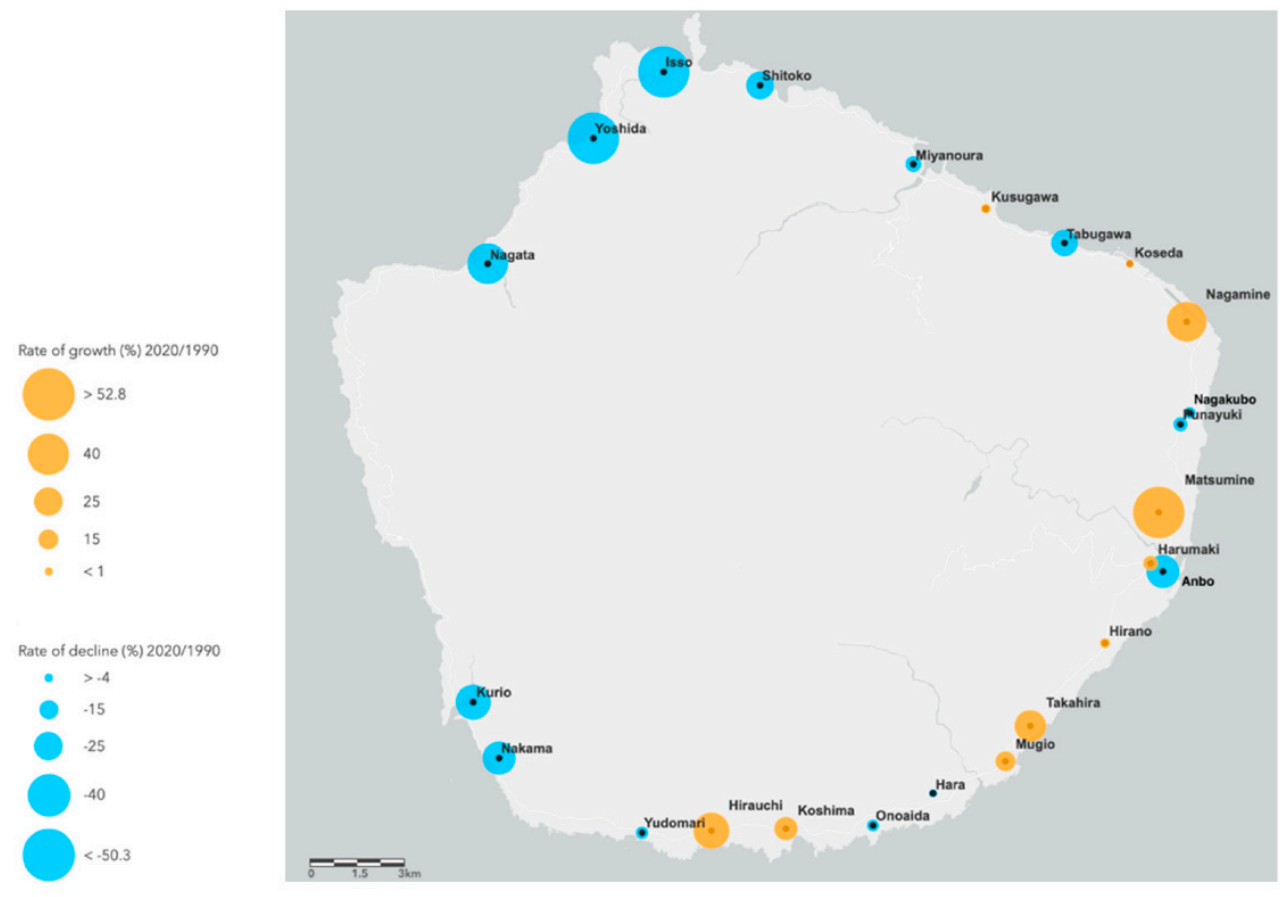

Figure 4. Changes in population by village from 1990 to 2020.

\subsection{Interview Results in 2009-2011}

The results of the semi-structured interviews conducted with tourism businesses between 2009 and 2011 are presented in Table 2. We conducted 46 interviews with a focus on accommodation facilities, guides, and shops. Twenty-three respondents originally came from Yakushima, 19 from outside the island, and in 4 cases, especially larger organizations or hotels, the place of origin was not clarified. Four in-migrants came from nearby Southern Kyushu, 10 from the Tokyo and Osaka metropolitan areas, 2 from other rural parts of Japan, and 3 did not specify. Among those respondents born in Yakushima, 10 confirmed that they left the island for a certain period and later returned (i.e., they conducted a so-called U-turn). Seven of the eight guides we interviewed moved to Yakushima from outside the island (i.e., they I-turned). This result correlates with the aforementioned tendency that guiding is a profession that is easily accessible for in-migrants. Only one of the guides originally came from Yakushima but spent two to three years outside the island. For all other types of businesses, residents outnumbered in-migrants. Most accommodation facilities examined were small scale, with capacities between 8 and 45 persons. Two larger hotels (with a capacity of 94 and 250 persons, respectively) explained that they employ staff from outside the island and local part-time workers. However, information on the interviewee himself was not given, and the number of in-migrants connected with these hotels could not be confirmed.

Table 2. Number of respondents by type of business and place of origin.

\begin{tabular}{ccc}
\hline Type of Business & No. of Respondents & No. of Respondents from Yakushima \\
\hline Accommodation & 17 & 10 \\
Shop & 11 & 7 \\
Restaurant, Cafe & 2 & 1 \\
Guide & 8 & 1 \\
Transport & 1 & 1 \\
Tourism facility & 4 & 3 \\
Organization & 3 & 0 \\
\hline
\end{tabular}


The businesses or organizations represented by the respondents were founded during different periods. Seventeen businesses started operating before 1992, when the island was not yet registered as a World Heritage site (period 1), 13 in the following 10 years between 1993 and 2002 (period 2), and 14 after 2003 (period 3). By type of business, accommodation facilities started operating in all three periods, whereas seven guides started after the World Heritage registration, when tourist numbers increased. Shops and tourist facilities, such as museums and organizations, often predated this period.

Looking at the connection between place of origin and start of business (Figure 5), businesses owned or managed by in-migrants dominated in 1993-2002, which is when most guides started their work. Local businesses were either founded before 1993 or after 2003. In one of the interviews, a local accommodation owner confirmed that after Yakushima's inhabitants witnessed the increase in tourists up to 2007, some started to invest in the tourism business. Another owner explained that she owned a house that she no longer used, so she put it on the market as simple accommodation without meals after consulting with the Chamber of Commerce.

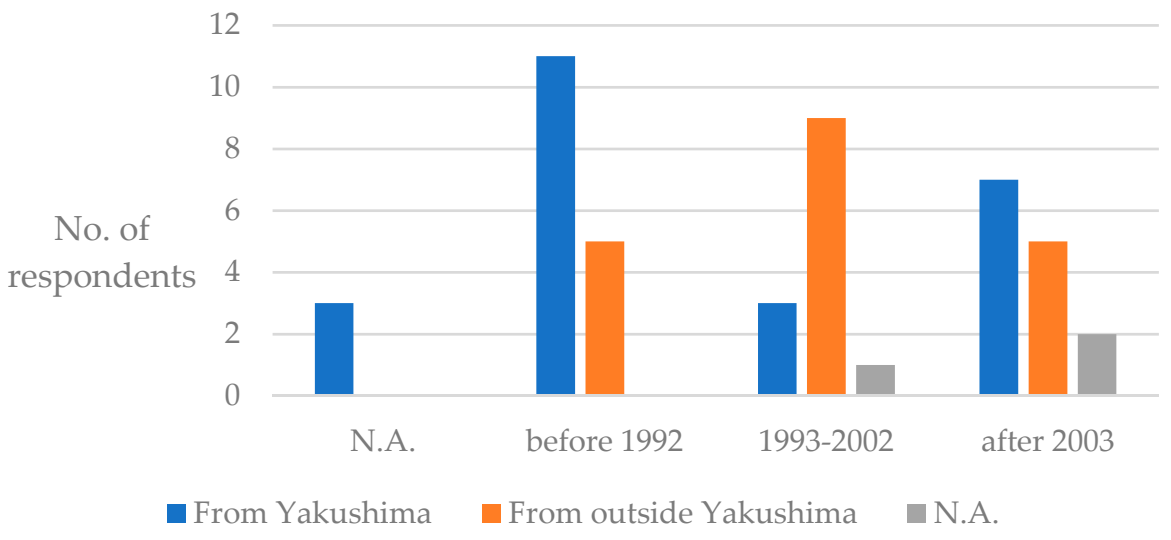

Figure 5. Year of the start of the business and place of origin.

As all locations were visited during the interviews, further differentiating locations and contents between businesses founded by residents and those founded by in-migrants was possible. Accommodation facilities run by in-migrants are located outside existing villages, often surrounded by nature. Whereas the facilities run by locals comprise mostly Japanese-style inns, in-migrant respondents explained that they deliberately chose types so far not represented on the island, such as youth hostels or Western-style inns. Shops run by local residents either sell a mix of everyday and tourism products or souvenirs from the island, including craft products made from cedar wood. In-migrants, on the other hand, offer products so far not available on the island, such as bakery, pottery, or outdoor goods designed with Yakushima motifs. Three of the visited tourism facilities were run by the town and employed residents.

Among the respondents who migrated to Yakushima, 11 explained their motivation and how they became involved in their current work. These can be summarized into the following categories, which sometimes overlap:

1. Early retirement: In-migrants retire early to move to the south and to nature. They use retirement payments from their companies to build accommodation facilities located in natural surroundings.

2. Nature: Many in-migrants are attracted by certain features of nature, especially mountains, water, or trees. The possibility of working in nature and the work experience in this sector further enhance this motivation.

3. Family reasons: People move to Yakushima to create a good environment for their children or to provide healthy surroundings for sick family members.

4. Chance: Some respondents are invited to join an activity or facility when traveling in Yakushima or through friends. 
5. Change: Looking for something different, the respondents end up in Yakushima.

As for U-turners, coming back for family or family businesses is an important motive. One interviewee explained that he came back to look after his family, and he started a restaurant because there was no other work available. For all respondents, moving to Yakushima to live close to nature was the prime motivation, whereas the choice of economic activity was secondary.

\subsection{Results of the 2015 Questionnaire Survey}

The demographic characteristics of the questionnaire respondents are shown in Table 3. The respondents were evenly distributed in terms of gender, and $51.8 \%$ of those who were involved in the tourism business were originally from outside Yakushima Island. The length of the respondents' residency in Yakushima reveals that only a few $(14.9 \%)$ are lifelong residents, with $29.8 \%$ having left the island for some time and returning as U-turners. The accommodation business is the most common one relating to tourism in Yakushima, so it has the highest percentage among the respondents (44.7\%). On the other hand, because the questionnaire was distributed through direct visits to the facilities, the percentage of tour guides was low, as most did not maintain a permanently staffed office. The majority of the businesses surveyed (58.8\%) were owned by the respondents or their family members. The results revealed that $67.5 \%$ of the respondents migrated to Yakushima after it became a UNESCO WNHS in 1993, with the majority of this inmigration occurring after tourism peaked in the island. Accordingly, a higher number of the businesses surveyed (67.7\%) started after 1993.

Table 3. Profile of the 2015 survey respondents in Yakushima.

\begin{tabular}{|c|c|c|c|}
\hline Variable & & $\mathrm{n}=114$ & $\%$ \\
\hline \multirow{3}{*}{ Gender } & Male & 51 & 44.7 \\
\hline & Female & 51 & 44.7 \\
\hline & Missing values & 12 & 10.6 \\
\hline \multirow{3}{*}{ Place of origin } & $\begin{array}{l}\text { From outside } \\
\text { Yakushima }\end{array}$ & 59 & 51.8 \\
\hline & From Yakushima & 46 & 40.4 \\
\hline & Missing values & 9 & 7.8 \\
\hline \multirow{4}{*}{ Residency type } & $\begin{array}{l}\text { Lived in Yakushima } \\
\text { since birth }\end{array}$ & 17 & 14.9 \\
\hline & I-turn & 57 & 50.0 \\
\hline & U-turn & 34 & 29.8 \\
\hline & Missing values & 6 & 5.3 \\
\hline \multirow{8}{*}{ Type of business } & Accommodation & 51 & 44.7 \\
\hline & Restaurant & 23 & 20.2 \\
\hline & Souvenir shop & 10 & 8.8 \\
\hline & Rental car & 8 & 7.0 \\
\hline & Guide & 6 & 5.3 \\
\hline & $\begin{array}{l}\text { More than two } \\
\text { businesses }\end{array}$ & 9 & 7.9 \\
\hline & Others & 5 & 4.4 \\
\hline & Missing values & 2 & 1.7 \\
\hline \multirow{7}{*}{ Position at facility $(\mathrm{n}=112)$} & Owner & 48 & 42.1 \\
\hline & Manager & 15 & 13.2 \\
\hline & Owner's family & 19 & 16.7 \\
\hline & Manager's family & 8 & 7.0 \\
\hline & Staff & 21 & 18.4 \\
\hline & Others & 1 & 0.9 \\
\hline & Missing values & 2 & 1.8 \\
\hline
\end{tabular}


Table 3. Cont.

\begin{tabular}{cccc}
\hline Variable & & $\mathbf{n}=\mathbf{1 1 4}$ & \% \\
\hline & $\leq 1992$ & 28 & 31.8 \\
Year of migration to Yakushima $(\mathrm{n}=88)$ & $1993-2000$ & 17 & 19.3 \\
& $2001-2007$ & 14 & 15.9 \\
& $2008-2015$ & 27 & 30.7 \\
Year business started & Missing values & 2 & 2.3 \\
& $\leq 1992$ & 32 & 16.7 \\
& $1993-2000$ & 19 & 21.9 \\
& $2001-2007$ & 25 & 20.2 \\
\end{tabular}

The results presented in Table 4 show the migration patterns of the respondents from and to Yakushima. Based on the results, the majority of outgoing migration from Yakushima occurred before its designation as an WNHS (83.9\%). Although in-migration to the island increased after its designation (I-turn $=74.1 \%$; U-turn $=53.6 \%$ ), a higher percentage of I-turn in-migration occurred after tourism on the island reached its peak in 2007, whereas a noticeable percentage of U-turn migration to the island occurred before the peak of tourism in Yakushima.

Table 4. Migration patterns of the respondents.

\begin{tabular}{|c|c|c|c|c|c|}
\hline \multirow{2}{*}{\multicolumn{2}{|c|}{ Migration Pattern }} & \multicolumn{4}{|c|}{ Year of Migration n (\%) } \\
\hline & & \multirow{2}{*}{$\begin{array}{c}\leq 1992 \\
26(83.9)\end{array}$} & \multirow{2}{*}{$\begin{array}{c}1993-2000 \\
2(6.5)\end{array}$} & \multirow{2}{*}{$\begin{array}{c}2001-2007 \\
2(6.5)\end{array}$} & \multirow{2}{*}{$\begin{array}{c}2008-2015 \\
1(3.2)\end{array}$} \\
\hline $\begin{array}{l}\text { Migrated from } \\
\text { Yakushima }\end{array}$ & $\begin{array}{l}\text { U-turn, left } \\
\text { Yakushima } \\
\quad(\mathrm{n}=31)\end{array}$ & & & & \\
\hline \multirow{2}{*}{$\begin{array}{l}\text { Migrated to } \\
\text { Yakushima }\end{array}$} & $\begin{array}{l}\text { U-turn to } \\
\text { Yakushima } \\
(\mathrm{n}=28)\end{array}$ & $13(46.4)$ & $5(17.9)$ & $7(25.0)$ & $3(10.7)$ \\
\hline & $\begin{array}{l}\text { I-turn to } \\
\text { Yakushima } \\
(\mathrm{n}=58)\end{array}$ & $15(25.9)$ & $12(20.7)$ & $7(12.1)$ & $24(41.4)$ \\
\hline
\end{tabular}

The results of the relationship between place of origin and type of business, position at the facility, and the year the business started are presented in Figure 6. Although there is no statistically significant difference in the relationship between place of birth and type of business, the figure below shows that in-migrants are more involved in tourism businesses than those respondents originally from Yakushima. However, their involvement is mainly as managers or staff, with the majority of business owners being from Yakushima. A statistically significant difference of 0.03 was found in the relationship between place of birth and the year the business started. The businesses that were established before Yakushima became a WNHS were predominantly owned by people from the island, whereas those after designation as a WNHS were mainly owned by in-migrants. It was discovered that the majority of businesses that started after the island's WNHS status were established in 2008-2015. 


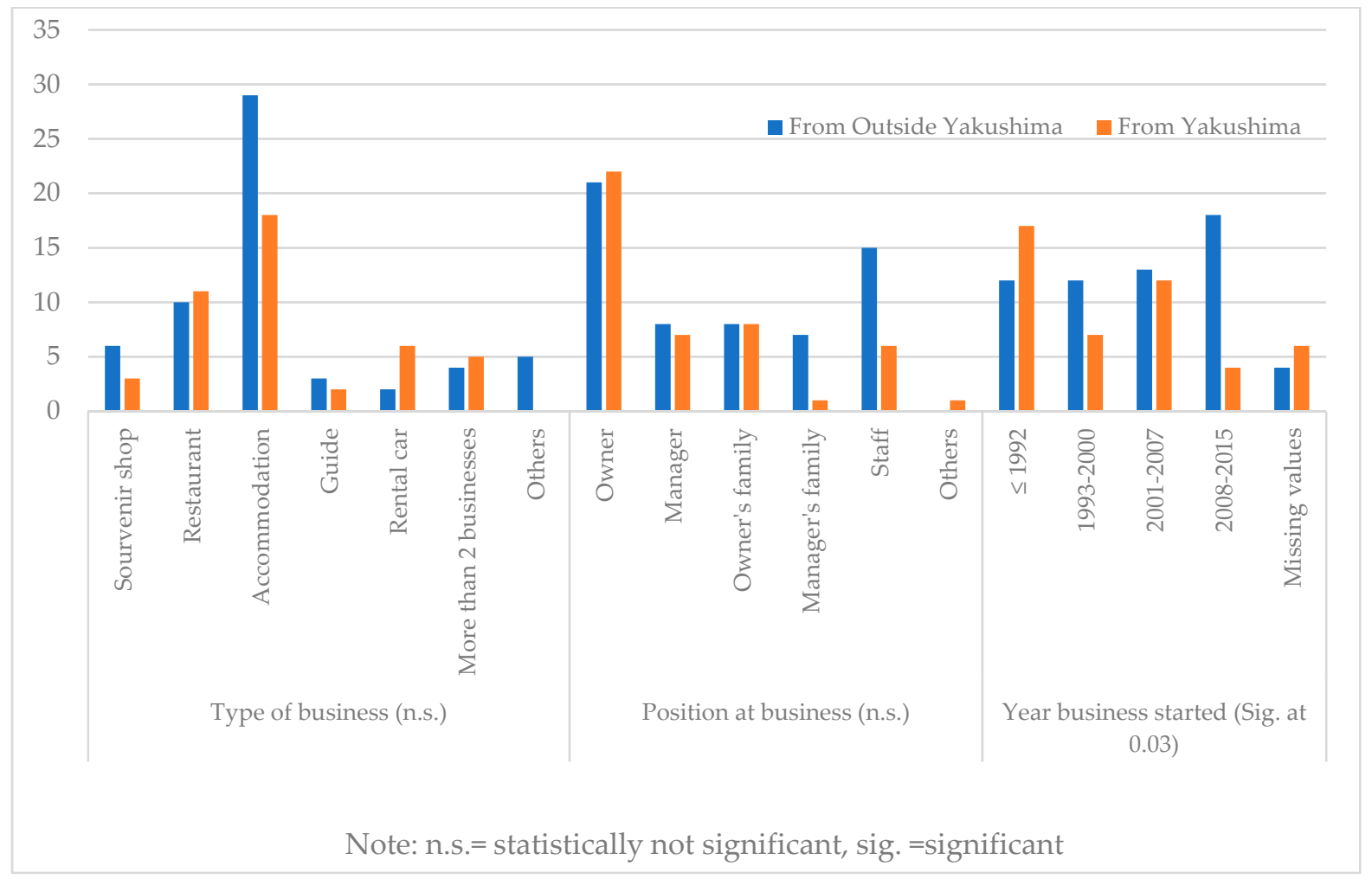

Figure 6. Relationship between place of origin, type of business, position at the facility, and year the business started.

\subsection{Results of the 2017 and 2018 Fieldwork}

In 2017 and 2018, semi-structured interviews were conducted with 16 tour guides who migrated to Yakushima, of which 14 were male and two were female. Table 5 shows the information on the respondents, including their period of moving to Yakushima Island and their age when they did so. Fourteen respondents in-migrated after the island's designation as a WNHS in 1992. All respondents moved to the island when they were in their 20s or 30s.

Table 5. Demography of in-migrated tour guides.

\begin{tabular}{ccc}
\hline \multirow{3}{*}{ Period of migration } & & Number of Respondents \\
\cline { 2 - 3 } & $1970 \mathrm{~s}$ & 1 \\
\cline { 2 - 3 } & $1990 \mathrm{~s}$ & 3 \\
\cline { 2 - 3 } & $2000 \mathrm{~s}$ & 7 \\
\hline Age upon migrating to \\
Yakushima & $2010 \mathrm{~s}$ & 5 \\
\cline { 2 - 3 } & $20 \mathrm{~s}$ & 6 \\
\hline
\end{tabular}

While the natural environment of Yakushima played an important role in attracting in-migrants, there was a clear difference in how tourism contributed to the decision to move between the groups who moved to Yakushima before and after the 2000s. For those who moved in the 1970s and 1990s, tourism was not a precursor of migration. One respondent moved to the island in 1977 with his father to start a pineapple farm. Another respondent originally came to Yakushima as a national park ranger. He worked for the Ministry of Environment for three years and later founded his own tour guide company. Similarly, another guide who relocated to Yakushima in 1994 originally came for his previous work.

Tourism contributed to the decision to move to Yakushima for those in-migrants who relocated after 2000, as all of them visited the island at least once before their settlement. 
Many of them had a specific purpose of moving, which was to become a tour guide. Consequently, Yakushima was chosen, as it is one of the few places in Japan where one can make a living as a tour guide. Some push factors that drove the respondents to move to Yakushima Island were mentioned during the interview. Three respondents stated that they were sick of living in the city and needed a change. One of them mentioned that the 2011 Tōhoku earthquake and tsunami disaster were the main triggers behind his decision to move out of the city.

When deciding where to move, some in-migrants had other places in mind besides Yakushima, such as Nagano Prefecture, where the Japanese Alps were located, and Okinawa in Southern Japan. They ended up choosing Yakushima, as it had everything from relatively high mountain peaks, rivers, and the sea. One respondent said, "Yakushima's forest is one of a kind and cannot be found in any other parts of Japan" (respondent A). While many of them liked to be in nature, and this was the reason for migration, some also mentioned that their positive experience with people when visiting Yakushima was another factor that motivated them to move to the island. For instance, one respondent stated, "The reason I moved to Yakushima was the people I met on the island. I had a nice experience with them. They were welcoming" (respondent B). Positive interactions with Yakushima tour guides were also the reason why some in-migrants relocated to Yakushima and begin working as tour guides.

Although being a tour guide is an established job in Yakushima, much tourism activity on the island is seasonal, concentrated in the spring, summer, and autumn. During the off-tourist season, when there are few clients, some tour guides help farmers harvest crops, such as tankan oranges, a local specialty fruit. Others spend a few months outside the island. Three respondents had other jobs besides working as a tour guide: one worked as a high school teacher, another ran a café and nonprofit organization, and the other respondent was involved in forestry.

While some in-migrants have been residing in Yakushima for years, an additional interview with town officials in Yakushima and personal communications with some locals and in-migrants revealed that there seems to be a certain number of in-migrants who moved out of the island after a while or are unwilling or unable to integrate into existing communities. The town officials were uncertain about why some in-migrants moved out, but they assumed that a limited job opportunity was one of the main reasons. Housing can also be another reason. Some in-migrants contact town officials because they are unable to find a place to live. To help them find a home, officials began providing a program for in-migrants in Yakushima in 2016. Officials mentioned that some villages were unwilling to cooperate with the town office in promoting the villages to potential in-migrants, which could be a barrier to revitalizing the island's population.

One local resident shared his experience with in-migrants and his own view of tourism's contribution to the island's sustainability:

"I gave a tour of my village to a lady who left Yakushima today ... The population of Yakushima did not decrease for a decade, but young in-migrants started moving out recently because of limited housing and poor internet connectivity. It can't be helped because they move to the island to get healed. You can't make a living just by wanting to get healed ... I think tourism declined because we ignored tourism development in the village area ... There are new restaurants, but at the same time, there are many that go out of business. In total, the number of restaurants is not increasing ... " During the fieldwork, the author (R.U.) met a young female in-migrant who originally moved to Nagata village on an island in the north. However, she was unable to integrate into the community and relocated to Miyanoura, the most populated village on the island. Although she was living in Miyanoura at the time of the fieldwork, she told the author that she wished to live in Nagata in the future, as she liked it the most. 


\subsection{Results of the 2017 and 2020 Interviews with International In-Migrants}

The steep increase in inbound tourism in Japan since 2013 has extended its influence to even remote parts of the archipelago. While domestic tourism is still dominant in Yakushima, international visitors have been increasing slowly. However, concerning population, out of 12,913 residents counted in the Population Census of 2015, only 73 were non-Japanese compared with 71 out of 13,761 residents in 2005 . The percentage of $0.6 \%$ is less than half the national average of $1.4 \%$. Through the interviews, we aimed to determine how the motives and business choices of international in-migrants differ from those of Japanese in-migrants. The characteristics of the respondents are presented in Table 6 . Further details from the interviews are summarized and not directly attributed to each individual in the table for privacy reasons.

Table 6. Demography of international in-migrants.

\begin{tabular}{|c|c|c|c|c|c|c|}
\hline Gender & Nationality & $\begin{array}{c}\text { Residence before } \\
\text { Yakishima }\end{array}$ & Job(s) & $\begin{array}{l}\text { Job(s) before } \\
\text { Yakushima }\end{array}$ & $\begin{array}{l}\text { In-Migrated } \\
\text { with }\end{array}$ & Year of Move \\
\hline Male & $\mathrm{NZ}$ & $\mathrm{NZ}$ & AirBnB, Rental car & $\begin{array}{c}\text { Tourism (ski guide, } \\
\text { etc.) }\end{array}$ & $\begin{array}{c}\text { Partner } \\
\text { (Japanese) }\end{array}$ & 2017 \\
\hline Male & USA & USA & Graphic designer & Graphic designer & $\begin{array}{c}\text { Family } \\
\text { (Japanese wife) }\end{array}$ & 2015 \\
\hline Male & USA & USA & Guide, farming & Gardener & $\begin{array}{l}\text { Alone (met his } \\
\text { wife in } \\
\text { Yakushima) }\end{array}$ & 2016 \\
\hline Male & $\mathrm{NZ}$ & Japan & Guide & $\begin{array}{c}\text { Guide, other tourism } \\
\text { work }\end{array}$ & $\begin{array}{c}\text { Family } \\
\text { (Japanese wife) }\end{array}$ & 2011 \\
\hline Male & UK & Japan & $\begin{array}{c}\text { Guide, English } \\
\text { language services }\end{array}$ & $\begin{array}{c}\text { Music event } \\
\text { organizer }\end{array}$ & $\begin{array}{c}\text { Family } \\
\text { (Japanese wife) }\end{array}$ & 2010 \\
\hline Female & USA & $\begin{array}{c}\text { Japan for } 9 \text { years, } \\
\text { then USA }\end{array}$ & Guide & $\begin{array}{l}\text { Studied sports in a } \\
\text { Japanese university }\end{array}$ & Alone & 2012 \\
\hline
\end{tabular}

Even among six interviewees, their motivations to move to Yakushima differed greatly. Although all male interviewees had Japanese partners, only one of them had direct family connections with the island and had visited several times before moving there. Another married a Japanese woman who had in-migrated to Yakushima herself. While two couples had considered Okinawa and other islands in southern Japan before settling in Yakushima, three other respondents decided to live on the island rather spontaneously after just one visit. For two couples, affordable property and living costs compared with those in their former living environment abroad were a decisive factor. One respondent from New Zealand stated that his wife had promised her family to stay in Japan, so he was very happy to find Yakushima, as the island's nature and culture reminded him of his home. Two mentioned that it seemed like a good place to start a family. Nature, the sea, and the fact that Yakushima was less developed than other islands all played a role. Five of the interviewees bought or built their own house(s). On the other hand, the only female respondent left Yakushima in 2020 to go back to graduate school in the US after working on the island as a guide for eight years.

Even without former experience, in-migrants chose guiding as their preferred profession, which was supported by an increase in the number of international visitors. Only a graphic designer worked originally outside tourism, but this respondent later became involved in designing local restaurants, shops, and products. AirBnb was still a new form of accommodation in Japan when the couple from New Zealand started their business. The empty houses available on the island offered an affordable opportunity to expand to several facilities and a rental car service. Unused farmland gave another respondent the chance to start farming.

For all in-migrants in rural Japan, blending in with the local community was a difficult task. However, most interviewees explained that they encountered few problems because they had Japanese spouses and children; one even mentioned that he felt very welcome. 
All of them lived in the southeastern villages of the island, where newcomers were concentrated (see Figure 4 above). They also actively try to blend in by joining neighborhood and guide associations or local sports and traditional music activities. One guide stated, "We didn't want to be too successful too quickly; we wanted to develop local relationships first".

Foreigners come to live in Yakushima because, as one guide explained, "This place attracts very interesting people, people who just think differently. This is a kind of safe place to develop your alternative skills ... so some interesting people turn up in Yakushima". Another respondent mentioned that he felt Yakushima is very cosmopolitan. He pointed out that among foreigners, attitudes differ in that some emphasize business, whereas others focus more on a relaxed lifestyle. According to their opinion, the influx of international tourists and residents has led to a higher quality of services and accommodations, approaching international standards.

\section{Discussion}

\subsection{Population Trend by Village}

Yakushima Island experienced a rapid drop in its population during the 1960s, similar to many other rural communities in Japan. However, it has put the brakes on its population decline because of the increasing number of in-migrants. This change coincided with the period during which the island experienced its highest influx of tourists [46]. Yet, the number of tourists has been steadily declining since 2008, and tourism's influence on the long-term trend of in-migration is yet to be explored. Therefore, the aim of this research was to examine the longitudinal trend of counterurbanization in Yakushima Island associated with tourism development.

Our detailed investigation into the population trend by village in Yakushima revealed that some communities experienced population growth, whereas others saw a decline in their population. Those communities that underwent population growth were mainly concentrated in the southern and eastern parts of the island, whereas most of the communities in the northern and western parts shrank over the last two decades.

Several factors presumably contributed to the different population trends on the island. Accessibility is considered to be a key factor influencing settlement. Because of the island's geographical characteristics in which several high mountain peaks are located at the center of the island, the roads that connect communities run along the coastline. The east side of the island has the access points to the major tourist attractions (i.e., the main trail entrances to the Jōmonsugi cedar tree, moss forest, and Yakusugi Land), and the airport and ferry terminals are also located in this area. The time required to travel from the airport to the community in the far western and northern ends of the island by car, for instance, could easily take over an hour. Therefore, there is low accessibility on the western and northern sides of the island. On the other hand, living in the eastern part of the island with relatively high accessibility could potentially provide more business opportunities for in-migrants.

Despite the distance away from some of the tourist attraction spots, the airport, and ferry terminals, the population of several communities located in the south, such as Hirauchi, Takahira, Kojima, and Mugio, also grew. Weather might play a role in attracting in-migrants to these communities, as the southern part stays relatively warm and sunny. Besides the weather, the land in Hirauchi was actively sold for residential development after Yakushima Pineapple Company's business failed [57]. This has attracted in-migrants who moved after retirement, as well as those who wished to live in nature as early as the 1990s [57]. The interviewees also expressed that some villages in the north are more difficult for in-migrants to integrate into.

\subsection{In-Migration and the Tourism Business during the Growth Period}

Yakushima recorded the highest number of visitors in 2007-2008. The interviews in the first research period, from 2009 to 2011, were conducted right after this peak. Therefore, they reflect an expanding tourism market with many chances for business. Ecotour guiding was established in the 1990s as an innovative industry [45]; previous research has 
already pointed out its strong connection with migration [50]. The fact that it requires few investments but some specialized knowledge not easily acquired on the island made it the primary choice of in-migrants in the decade following the World Heritage designation. Accommodation, on the other hand, is divided between local businesses predating World Heritage designation, in-migrants investing retirement money to build new types of facilities surrounded by nature, and residents finding opportunities to put assets, such as land or buildings, to profitable use after they watch tourist numbers grow constantly. Shops could be differentiated between those where in-migrants brought or developed new products and those where residents provided traditional souvenirs or daily goods. As nature is the most important tourism attraction in Yakushima, tourism facilities consist mainly of publicly run museums and therefore had a very weak connection with migration. In-migrants contributed to innovation in tourism through the establishment of ecotour guiding, and they increased the diversity of accommodation and shops. This is in line with previous findings that in-migrants to natural or low-amenity areas frequently leverage resources to start tourism businesses [10,21]. However, their strong focus on nature limits their interest in the diversification of tourism attractions in Yakushima.

Nature proved to be the strongest attraction to in-migrants. More than half of the interviewees from outside Yakushima came from metropolitan areas looking for a place to live and work in nature. However, chance encounters while traveling in Yakushima or a strong wish for change also brought some respondents to the island. The deliberate choice of Yakushima as a destination for migration therefore contrasts with the motivation of a minority of chance in-migrants.

The findings of this study reveal that most of the respondents originally from Yakushima left the island at a point in time (see Table 3). This directly reflects the length of residency of the respondents, with just a small percentage being lifelong residents (see Table 3). Nonetheless, because of the tourism boom Yakushima experienced after becoming a WNHS, the island saw an influx of both U-turns and I-turns, resulting in a relatively stable population of the island for over two decades. As noted by previous studies, tourism has been found to contribute to demographic stabilization [26], the reduction in outgoing migration in rural areas [58], population growth [59], and positively impact the economy [11,12].

Furthermore, it was discovered that I-turners are more involved in the tourism business than people originally from Yakushima. However, the involvement of I-turns in tourism is predominantly as tour guides or as managers and staff at accommodation facilities (see Figure 6). The designation of Yakushima as a WNHS in 1993 and its subsequent tourism growth resulted in the establishment of more tourism-related businesses during this period. However, tourism reaching its peak in 2007 attracted more I-turners to migrate to the island and become involved in the tourism business. This is evident in Table 4, with the highest percentage of I-turners moving to Yakushima recorded between 2008 and 2015, and in Figure 6, in which more I-turners work in businesses that started after 2007. These findings are in line with those of previous research, noting that rural tourism has some of the factors that attract I-turners to relocate to rural and remote areas [7].

\subsection{In-Migration Post-Growth Period}

As shown in Figure 2, tourists in Yakushima have been steadily decreasing in number for the last decade, and it can be considered that tourism in Yakushima may have reached its stagnation or decline period. The fieldwork in 2017, 2018, and 2020 was conducted during such a period, allowing us to explore changes, if any, in the counterurbanization trend occurring in Yakushima. Our interviews with multiple tour guides allowed us to compare motivations to move to Yakushima across different settlement periods. All of the tour guides we interviewed moved to the island when they were relatively young. For many, tourism is the precursor to migration, which is consistent with what has been found in previous research $[8,9]$. Yakushima's rich nature, including the sea, rivers, and mountains, is what attracted these in-migrants. In addition to nature, connection with people in Yakushima was found to be another key factor attracting some in-migrants to the island. In 
previous studies, property prices [7] and natural features $[17,18]$ have been identified as the motivations for migrating to a tourism destination. However, the aspects of communication and human relations have not been studied thus far.

Interviews with Yakushima town officials and some locals revealed that some inmigrants had moved out of the island. Seeking a job was one reason given for doing so, considering that many in-migrants are involved in tourism businesses and that tourist numbers are decreasing. Housing unavailability was also found to be a barrier to potential in-migrants who plan to move to the island.

Although tourism has been at a declining stage and seems to have affected some Japanese in-migrants, we found that several international in-migrants have been moving to Yakushima. They showed similar diversity to the Japanese in terms of their motivation to move to Yakushima. Lifestyle for some could mean carefully choosing a place to start a family or business, whereas for others, accepting chance encounters with a person or the island was their way to build their lives. As typical motives for urban-to-rural migration, lower property rates and the availability of second-hand houses and farmland helped attract international in-migrants. The islands' natural environment proved to be an important relocation factor. As a common feature, international in-migrants promote innovations, such as AirBnb, guidance of international visitors, comprehensive arrangements of tours, accommodations, and rental cars or new designs, mirroring changes in the Japanese tourism market as a whole and helping the quality of Yakushima's tourism industry reach international standards.

\section{Conclusions}

The overarching objective of this study was to identify the long-term connection between tourism and counterurbanization at a low-amenity, peripheral island destination. We identified the motivations and factors that create an attractive destination for in-migrants to Yakushima Islands and the contribution of in-migration to the population stabilization of a low-amenity rural area.

Our study confirmed that Yakushima's nature has been and continues to be a strong driver for in-migrants regardless of their occupation, age, and different tourism development stages. The characteristics of in-migrants to Yakushima are similar to those found in previous studies in that they seek a better environment and are unsatisfied with their previous lifestyle in urban areas. Over a decade, the profile of in-migrants has diversified from elderlies who seek a slow life after retirement to younger generations who aspire to work as tour guides, and to international migrants catering to international tourists. Throughout the period, in-migrants helped innovate the tourism sector in several areas, including guiding, accommodation, souvenirs, and marketing, thus increasing tourism amenities. However, with a strong focus on nature as a major motive for migration, they did not induce a diversification of nature-based tourism on the island.

The study contributes to the literature on the role of tourism in counterurbanization in the particular context of peripheral island tourism destinations. It also contributes to the literature in the fields of geography and sociology by shedding light on the factors influencing motivation to migrate to scarcely populated regions, especially nature-based tourism destinations. Particularly, it provides practical contributions and ideas for the management of tourism destinations, specifically islands, to design strategies that prevent the loss of in-migrants, even when there is a decline or stagnation in tourism. Although our study shows that tourism is a factor for counterurbanization, there is a need for further research that explores different theories of motivation for counterurbanization and its connection with tourism. As observed in our study, the out-migration of in-migrants became an emerging problem after tourist numbers declined, so research can be carried out in the future to examine the effects of tourism decline on migration patterns, the tourism business, and employment in low-amenity rural areas. Identifying the barriers to the longterm settlement of in-migrants is suggested, which include job and housing unavailability, as well as poor internet connectivity. 
Author Contributions: Conceptualization, R.U., C.F. and I.B.A.; methodology, R.U., C.F. and I.B.A.; software, I.B.A.; validation, R.U., C.F. and I.B.A.; formal analysis, R.U., C.F. and I.B.A.; investigation, R.U., C.F. and I.B.A.; resources, R.U., C.F. and I.B.A.; data curation, R.U., C.F. and I.B.A.; writingoriginal draft preparation, R.U., C.F. and I.B.A.; writing-review and editing, R.U., C.F. and I.B.A.; visualization, R.U. and I.B.A.; supervision, C.F.; project administration, R.U., C.F. and I.B.A.; funding acquisition, C.F. All authors have read and agreed to the published version of the manuscript.

Funding: Fieldwork in 2009-2011 by C.F. was supported by the 21st Century Science Projects of the Graduate School of Integrated Arts and Sciences (Hiroshima University). Fieldwork in 2015 by I.B.A., C.F. and R.U. was supported by the 21st Century Science Projects of the Graduate School of Integrated Arts and Sciences (Hiroshima University) and by the Japan Society for the Promotion of Science Grant-in-Aid for Scientific Research Project JP26360065 (C.F.). Fieldwork in 2020 by C.F. was supported by the Japan Society for the Promotion of Science Grant-in-Aid for Scientific Research Project JP20K12400 (C.F.) The author (R.U.) was supported by the Hiroshima University TAOYAKA Program for creating a flexible, enduring, peaceful society, funded by the Program for Leading Graduate Schools, Ministry of Education, Culture, Sports, Science, and Technology at the time of the fieldwork in 2017 and 2018.

Institutional Review Board Statement: Not applicable.

Informed Consent Statement: Informed consent was obtained from all subjects involved in the study.

Data Availability Statement: The datasets analysed during the current study are available from the corresponding author on reasonable request.

Acknowledgments: We thank our respondents for sharing their insights.

Conflicts of Interest: The authors declare no conflict of interest.

\section{References}

1. Williams, A.M.; Hall, C.M. Tourism and migration: New relationships between production and consumption. Tour. Geogr. 2000, 2, 5-27. [CrossRef]

2. Mitchell, C.J.A. Making sense of counterurbanization. J. Rural Stud. 2004, 20, 15-34. [CrossRef]

3. Hall, C.M.; Müller, D.K. Tourism, Mobility and Second Homes: Between Elite Landscape and Common Ground; Channel View Publications: Clevedon, UK, 2004; pp. 1-320.

4. Torkington, K. Defining lifestyle migration. Dos Algarves Multidiscip. E J. 2010, 19, 99-111.

5. O'Reilly, K.; Benson, M. Lifestyle migration: Escaping to the good life? In Lifestyle Migration; Benson, M., O'Reilly, K., Eds.; Ashgate Publishing: Surry, UK, 2009; pp. 1-13.

6. Phillips, M. Other geographies of gentrification. Prog. Hum. Geogr. 2004, 28, 5-30. [CrossRef]

7. Unguren, E.; Tekin, Ö.A.; Bayirli, M. Exploring the effect of push and pull motivation factors on destination satisfaction: Empirical evidence from amenity migration perspectives. Eur. J. Tour. Res. 2021, 28, 2811.

8. Casado-Díaz, M.A.; Casado-Díaz, A.B.; Casado-Díaz, J.M. Linking tourism, retirement migration and social capital. Tour. Geogr. 2014, 16, 124-140. [CrossRef]

9. Nelson, K.; Black, R.; Bamberry, L. Second life: Liminal tourism spaces as sites for lifestyle migration, an exploration of Niseko, Japan. J. Hosp. Tour. 2021, 47, 294-302.

10. Carson, D.A.; Carson, D.B.; Eimermann, M. International winter tourism entrepreneurs in northern Sweden: Understanding migration, lifestyle, and business motivations. Scand. J. Hosp. Tour. 2018, 18, 183-198. [CrossRef]

11. Eimermann, M. Two sides of the same coin: Dutch rural tourism enterpreneurs and countryside capital in Sweden. Rural Soc. 2016, 25, 55-73. [CrossRef]

12. Iversen, I.; Jacobsen, J.K. Migrant tourism entrepreneurs in rural Norway. Scand. J. Hosp. Tour. 2016, 16, 484-499. [CrossRef]

13. Carlsen, J.; Morrison, A.; Weber, P. Lifestyle oriented small tourism firms. Tour. Rec. Res. 2008, 33, 255-263. [CrossRef]

14. Peters, M.; Frehse, J.; Buhalis, D. The importance of lifestyle entrepreneurship: A conceptual study of the tourism industry. PASOS Rev. Tur. Patrim. Cult. 2009, 7, 393-405. [CrossRef]

15. Lundberg, C.; Fredman, P. Success factors and constraints among nature-based tourism entrepreneurs. Curr. Issues 2012, 15, 649-671. [CrossRef]

16. Shaw, G.; Williams, A. From lifestyle consumption to lifestyle production: Changing patterns of tourism entrepreneurship. In Small Firms in Tourism: International Perspectives; Thomas, R., Ed.; Elsevier: Amsterdam, The Netherlands, $2004 ;$ pp. 99-114.

17. Vuin, A.; Carson, D.A.; Carson, D.B.; Garret, J. The role of heritage tourism in attracting "active" in-migrants to "low amenity" rural areas. Rural Soc. 2016, 25, 134-153. [CrossRef]

18. Persson, L. Lifestyle migrants or "environmental refugees"?-Resisting urban risks. Popul. Space Place 2019, 25, 1-12. [CrossRef]

19. Lundmark, L.; Ednarsson, M.; Karlsson, S. International migration, self-employment and restructuring through tourism in sparsely populated areas. Scand. J. Hosp. Tour. 2014, 14, 422-440. [CrossRef] 
20. Sun, X.; Xu, H.; Köseoglu, M.A.; Okumus, F. How do lifestyle hospitality and tourism entrepreneurs manage their work-life balance? Int. J. Hosp. Manag. 2020, 85, 102359. [CrossRef]

21. Kuentzel, W.; Ramaswamy, V. Tourism and amenity migration: A longitudinal analysis. Ann. Tour. Res. 2005, 32, 419-438. [CrossRef]

22. Bijker, R.; Haartsen, T.; Strijker, D. Migration to less-popular rural areas in the Netherlands: Exploring the motivations. J. Rural Stud. 2012, 28, 490-498. [CrossRef]

23. King, R. Geography, islands and migration in an era of global mobility. Isl. Stud. 2009, 4, 53-84.

24. Baum, T. The fascination of islands: A touristic prospective. In Island Tourism: Trends and Prospects; Lockhart, D., Drakakis, S.D.W., Eds.; Pinter: London, UK, 1997; pp. 21-36.

25. Connell, J. Island migration. In A World of Islands: An Island Studies Reader; Baldacchino, G., Ed.; Agenda Academic Publishers: Luqa, Malta, 2007; pp. 455-481.

26. Connell, J. Islands: Balancing development and sustainability? Environ. Conserv. 2018, 45, 111-124. [CrossRef]

27. Ibănescu, B.C.; Stoleriu, O.M.; Munteanu, A.; Iațu, C. The Impact of Tourism on Sustainable Development of Rural Areas: Evidence from Romania. Sustainability 2018, 10, 3529. [CrossRef]

28. Kuwahara, S. The development of small islands in Japan: An historical perspective. J. Mar. Isl. Cult. 2012, 1, 38-45. [CrossRef]

29. Adrianto, L.; Matsuda, Y. Study assessing economic vulnerability of small island regions. Environ. Dev. Sustain. 2004, 6, 317-336. [CrossRef]

30. Kim, H.; Kim, E.J. Tourism as a key for regional revitalization?: A quantitative evaluation of tourism zone development in Japan. Sustainability 2021, 13, 7478. [CrossRef]

31. Lützeler, R.; Manzenreiter, W.; Polak-Rottmann, S. Introduction: Japan's new ruralities. In Japan's New Ruralities: Coping with Decline in the Periphery; Manzenreiter, W., Lützerler, R., Polak-Rottmann, S., Eds.; Routledge: London, UK, 2020 ; pp. 1-24.

32. Funck, C. Tourism and Periphery in Japan: The Potential of Tourism Development in order to Redress Regional Disparities; Verlag Dieter Born: Bonn, Germany, 1999; pp. 1-344.

33. Funck, C.; Cooper, M. Japanese Tourism: Spaces, Places and Structures; Berghahn: New York, NY, USA, 2013 ; pp. 1-243.

34. Reiher, C. Embracing the periphery: Urbanites' motivations for relocating to rural Japan. In Japan's New Ruralities: Coping with Decline in the Periphery; Manzenreiter, W., Lützeler, R., Polak-Rottmann, S., Eds.; Routledge: New York, NY, USA, 2020; pp. 230-244.

35. Klien, S. Urban Migrants in Rural Japan; State University of New York Press: New York, NY, USA, 2020; pp. 1-203.

36. Funck, C. Has the island lure reached Japan? Remote islands between tourism boom, new residents, and fatal depopulation. In Japan's New Ruralities: Coping with Decline in the Periphery; Manzenreiter, W., Lützerler, R., Polak-Rottmann, S., Eds.; Routledge: London, UK, 2020; pp. 177-195.

37. Tsutsui, K.; Sakuma, Y.; Kasami, K. Community development with migrants into rural areas under the social trend on "Den-en Kaiki -Return to rural living". Geogr. Sci. 2016, 71, 156-165.

38. Adewumi, I.B.; Usui, R.; Funck, C. Perceptions of multiple stakeholders about environmental issues at a nature-based tourism destination: The case of Yakushima Island, Japan. Environments 2019, 6, 93. [CrossRef]

39. Forbes, G. Yakushima: Balancing long-term environmental sustainability and economic opportunity. Kagoshima Immacul. Heart Coll. Res. Bull. 2012, 42, 35-49.

40. Tokumaru, H. Nature conservation on Yakushima Island: Kagoshima Prefecture's efforts. Glob. Environ. Res. $2003,7,103-111$.

41. Adewumi, I.B.; Funck, C. Ecotourism in Yakushima: Perception of the people involved in tourism business. Geogr. Sci. 2016, 71, 185-205.

42. Yakushima Town. 2015 Welcome to Yakushima \& Kuchinoerabujima; Yakushima Town: Yakushima, Japan, 2015 ; pp. 1-59.

43. Okano, T. Biodiversity in the islands of Kagoshima. In The Islands of Kagoshima; Kawai, K., Terada, R., Kuwahara, S., Eds.; Kagoshima University Research Center for the Pacific Islands: Kagoshima, Japan, 2013; pp. 136-145.

44. Marugami, Y.; Deguchi, A. Comparison study on process of forming brand image and preservation of regional resources in tourist areas. J. Arch. Plann. Res. 2015, 80, 351-360. [CrossRef]

45. D'Hauteserre, A.M.; Funck, C. Innovation in island ecotourism in different contexts: Yakushima (Japan) and Tahiti and its islands. Isl. Stud. J. 2016, 11, 227-244.

46. Fukami, S. Current situation and challenges of environmental conservation and ecotourism in Yakushima, Japan. Jpn. Tour. Res. Soc. Natl. Conven. Acad. Pap. Collect. 2011, 26, 425-428.

47. Yakushima Town. Population Census. 2020. Available online: http://www.town.yakushima.kagoshima.jp/t_yakushima/wpcontent/uploads/2021/01/32d7066acd08758e20caf6bcdb90f471.pdf (accessed on 16 June 2021).

48. Yakushima Town. Yakushima Statistics. 2016. Available online: http://www.town.yakushima.kagoshima.jp/t_yakushima/wpcontent/uploads/2017/05/8cdd5d1db7c50ebd9731a6ef0fdddeb5.pdf (accessed on 16 June 2021).

49. The Kagoshima Economic Research Institute. World Natural Heritage Yakushima. Tourism Master Plan Working Group DocumentFuture of Yakushima in Two Decades; Kagoshima Economic Research Institute Ltd.: Kagoshima, Japan, 2014.

50. Kanetaka, F.; Funck, C. The development of the tourism industry in Yakushima and its spatial characteristics. Stud. Environ. Sci. 2012, 6, 65-82.

51. Kagoshima Prefecture. The Status of Kumage Region. 2020. Available online: https://www.pref.kagoshima.jp/ap01/chiiki/ kumage/chiiki/r1kumagegaikyou.html (accessed on 16 July 2021). 
52. Official Certified Guides of Yakushima. The List of Certified Guides. 2016. Available online: http://www.yakushima-eco.com/ $\log$ / guide-list/ (accessed on 16 July 2021).

53. Yakushima Tourism Association. Guide List. n.d. Available online: http:/ / yakukan.jp/play/guide.html (accessed on 16 July 2021).

54. Robert, K.Y. Designing case studies: Identifying your case(s) and establishing the logic of your case study. In Case Study Research and Applications, 6th ed.; Sage: Los Angeles, CA, USA, 2018; pp. 25-66.

55. Yakushima Town. Population Census. 2021. Available online: http://www.town.yakushima.kagoshima.jp/t_yakushima/wpcontent/uploads/2021/05/202104_population.pdf (accessed on 20 May 2021).

56. Kagoshima Prefecture. Population Trend. 2020. Available online: https://www.pref.kagoshima.jp/ap01/chiiki/kumage/chiiki/ documents /80723_20200403171927-1.pdf (accessed on 16 June 2021).

57. Tajima, Y. New immigrants in Yaku Island, Kagoshima Prefecture. Bulletin of the Faculty of Education, Kagoshima University. Cult. Soc. Sci. 2000, 52, 41-59.

58. Androshchuk, L.; Chernenko, N. The economic and mathematical analysis of migration of employable population as a factor of national modernization in crisis. East. J. Eur. Stud. 2016, 7, 35-47.

59. Démurger, S.; Xu, H. Return migrants: The rise of new entrepreneurs in rural China. World Dev. 2011, 39, 1847-1861. [CrossRef] 